Global Conferences Series:

Social Sciences, Education and Humanities (GCSSSEH), Volume 6, 2020

International Conference Fakultas Tarbiyah dan Keguruan Universitas Islam Negeri Imam Bonjol Padang (ICFTKUINIBP) 2020

DOI: https://doi.org/10.32698/icftk419

\title{
Surau as an Alternative Education Institution in Realizing Independent Learning for Students
}

\section{Surau sebagai Lembaga Pendidikan Alternatif dalam Mewujudkan Pembelajaran Mandiri Bagi Siswa}

\author{
Rahmahidayati Sari \\ Institute Agama Islam Negeri Takengon, Aceh, Indonesia \\ E-mail: rahma.melkengibya@gmail.com
}

\begin{abstract}
Surau is one of the components that cannot be separated from the environment of the Minangkabau community. Teachers / Sheikhs provide teaching and experience to their students learning Islamic education and life skills needed by students. The subject matter provided by the teacher / sheikh is not only theoretical / content based on the book/ kitab being studied, but emphasizes understanding the meaning contained in each of these lessons. Merdeka belajar which was proclaimed by the Minister of Education and Culture of the Republic of Indonesia with several policies contained therein has provided a broader view of the real learning process. The concept of merdeka belajar is the competence of teachers at any level, without a translation process of the existing basic competencies and curriculum, no learning will ever occur. With the concept of "merdeka belajar", the surau can be used as an alternative for educational institutions in realizing the concept of merdeka belajar. Surau has several criteria that have met the existing policies of merdeka belajar. If possible, surau can also be used as one of the other educational institutions equivalent to formal education.
\end{abstract}

Keywords: Surau, education system, freedom of learning

\section{INTRODUCTION}

Kurikulum di Indonesia memiliki perubahan dari waktu ke waktu. Kurikulum pendidikan Indonesia pertama kali dan dinamakan "rencana pengajaran". Setelah itu, terjadi perubahan kurikulum menyesuaikan perubahan zaman dan kebutuhan pendidikan. Kita mengenal kurikulum CBSA, kurikulum 1994 sampai sengan terakhir yaitu kurikulum 2013 edisi revisi 2017.

Namun seluruh kurikulum yang telah ada sejak tahun 1947 sampai dengan tahun 2017 dirasakan oleh tenaga pendidik atau pengamat pendidikan belum mencapai kebutuhan dan tujuan pendidikan nasional. Apalagi dengan kurikulum 2013 edisi revisi 2017 memiliki tujuan yang baik dan bagus tetapi ada beberapa kelemahan yang terdapat dalam kurikulum tersebut (M.Asri, 2017:196-201).

Ini menimbulkan keprihatinan dari pengamat pendidikan dan masyarakat. Melihat kondisi pendidikan Indonesia yang demikian, Menteri pendidikan dan kebudayaan RI, Nadiem Makarim mencanangkan sebuah kurikulum sebagai solusi permasalahan yang ada. Solusi tersebut adalah dengan menerapkan pendidikan dengan sistem merdeka belajar.

Merdeka belajar merupakan sistem pendidikan yang berbeda dengan kurikulum sebelumnya. Merdeka belajar yang dicanangkan oleh Menteri pendidikan dan Kebudayaan, Nadiem Makarim pada tahun 2019 memberikan konsep program kebijakan baru dalam pendidikan dengan esensi kemerdekaan berpikir.

Esensi kemerdekaan berpikir harus didahului oleh para guru sebelum mereka mengajar siswa-siswi. Dimana pun kompetensi yang diinginkan, tanpa ada proses penerjemahan dari kompetensi dasar dan kurikulum yang ada oleh guru, maka tidak akan terjadi proses pembelajaran. (Wikipedia, 2020). Merdeka Belajar versi Mendikbud adalah mengaplikasikan kurikulum pada pembelajaran haruslah menyenangkan dan ditambah dengan pengembangan berpikir yang inovatif yang dikembangkan oleh guru. Konsep merdeka 
belajar ini dapat menumbuhkan sikap positif murid dalam merespon pembelajaran (Fathan, 2020). Merdeka belajar adalah pembelajaran yang dilakukan oleh guru dengan cara yang menyenangkan dan guru perlu mengembangkan cara berpikir yang inovatif sehingga dapat menumbuhkan sikap postif dari siswa dalam merespon pembelajaran dan siswa tidak hanya sekedar mengetahui konten pelajaran tetapi juga pemahaman terhadap makna dari pelajaran tersebut.

Diperkirakan untuk masa yang akan datang, dengan konsep merdeka belajar maka pembelajaran yang sebelumnya diharuskan dilakukan dalam kelas dapat dilakukan di luar kelas. Pembelajaran di luar kelas dapat memberikan pengalaman belajar yang lebih menyenangkan bagi siswa dan dapat membentuk karakter siswa yang mandiri, beradab, cerdik dalam bergaul, sopan, berani, berkompetensi dan tidak hanya mementingkan skor/ nilai dalam proses pembelajaran.

Konsep mandiri belajar yang dicanangkan oleh Menteri Pendidikan dan Kebudayaan RI pada tahun 2019, sebenarnya telah dilakukan oleh masyarakat Minangkabau pada masa lalu. Sistem Pendidikan Islam sesuai dengan konsep mandiri belajar telah dilakukan oleh Pendidikan Islam yang dilaksanakan di Surau.

Pendidikan Islam di surau lebih menekankan kepada pemahaman materi pelajaran yang dilakukan di Surau dan keterampilan hidup yang harus dikuasai oleh siswa. Materi yang diajarkan di Surau dipraktekkan oleh siswa nantinya ketika mereka telah kembali ke masyarakat dan kampungnya.

Surau merupakan salah satu lembaga pendidikan Islam berasal dari masyarakat membangun masyarakat Islam dan peletak dasar ajaran agama Islam yang ada di Minangkabau yang dianggap berhasil dimasa lampau (Mas'oed Abidin, 2016:22). Keberhasilan pendidikan Islam pada masyarakat Minangkabau pada saat itu ditandai dengan pandai mengaji, berakhlak, taat beribadah dan berkepribadian luhur. Karena dalam surau mereka mempelajari pendidikan Islam secara keseluruhan dan keterampilan hidup yang akan digunakan di tengah masyarakat setelah mereka menyelesaikan Pendidikan di Surau. Keberhasilan pendidikan Islam di Surau pada masa lalu dilihat dengan banyaknya ulama dan tokoh yang terkenal baik di tingkat nasional maupun internasional yang dihasilkan, seperti: Tuanku Imam Bonjol, Muhammad Hatta, HAMKA dan banyak tokoh lainnya.

Saat ini, Pendidikan Islam yang diadakan surau bukan lagi sebuah lembaga pendidikan Islam yang diperhitungkan yang dapat memberikan Pendidikan Islam secara kompleks. Surau hanya digunakan masyarakat Minangkabau sebagai tempat mengaji bagi anak-anak. Peran surau menyelenggarakan Pendidikan Islam tergantikan oleh pendidikan formal seperti madrasah dan pesantren modern. Walaupun begitu, ada beberapa hal yang ada dalam surau dapat ditiru dan dipakai oleh lembaga pendidikan formal terutama pendidikan Islam. Terutama dari segi sistem Pendidikan yang diterapkan oleh surau kepada siswanya. Sistem Pendidikan surau telah menerapkan konsep merdeka belajar yang dicanangkan Menteri Pendidikan dan Kebudayaan RI pada tahun 2019 dengan beberapa kebijakan yang terdapat didalamnya.

Dengan telah diterapkannya kebijakan merdeka belajar dilakukan oleh surau, surau bisa dijadikan sebagai salah satu lembaga pendidikan Islam alternatif dalam menciptakan meredeka belajar yang sesungguhnya.

\section{PEMBAHASAN}

\section{Hakikat Merdeka Belajar}

Merdeka belajar yang dicanangkan tahun 2019 sebenarnya memberikan pengertian secara luas bahwa belajar haruslah senang dan menyenangkan. Selain itu, merdeka belajar bertujuan untuk membuat pembelajaran lebih bermakna lagi. Adapun secara umum program ini bukan untuk menggantikan program yang telah berjalan, tujuan utamanya adalah memperbaiki sistem yang sudah ada. Merdeka belajar yang digagas Kemendikbud menawarkan proses pembelajaran yang lebih sederhana (wiku Ajisugiri, 2020: 54). Beberapa pembaharuan sistem Pendidikan di Indonesia dengan merdeka belajar yaitu (Kementrian Pendidikan dan Kebudayaan RI, 2020):

1. Kebijakan yang berkaitan dengan Ujian Nasional (UN). UN yang dilaksanakan saat ini dianggap kurang efektif melakukan evaluasi bagi siswa karena materi yang dievaluasi pada UN sangat padat, cenderung kepada penguasaan konten bukan kompetensi penalaran. Selain itu, indicator keberhasilan dalam UN adalah siswa sebagai individu sehingga menjadi beban bagi guru, siswa, orang tua dan sekolah. UN juga hanya menilai aspek kognitif siswa belum menilai karakter siswa secara keseluruhan.Dengan kondisi seperti diatas, merdeka belajar memberikan solusi atas beberapa permasalahan dalam UN yaitu tahun 2020 adalah terakhir kalinya pelaksanaan UN, tahun 2021 akan dilaksanakan asesmen kompetensi minimum dan survei karakter. Asesmen kompetensi minimum dan survei karakter akan dilaksanakan pada tengah jenjang sekolah dan tidak bisa dijadikan acuan seleksi siswa untuk melanjutkan ke tingkat Pendidikan selanjutnya. 
Serta pelaksanaan asesmen kompetensi minimum dan survei karakter mengacu pada praktik pada tingkat internasional.

2. Pelaksanaan UASBN membatasi keleluasaan sekolah untuk menentukan kelulusan siswa. Kurikulum 2013 adalah kurikulum yang mengingikan asesmen secara holistic. Permasalah dari UASBN ini akan dicoba diperbaiki dari kebijakan merdeka belajar yaitu mengganti UASBN dengan asesmen yang dilakukan oleh sekolah. Selain itu dalam pelaksanaan asesmen tersebut boleh dilakukan dengan tes tertulis dan/ atau penilaian lain yang lebih komprehensif. Serta asesmen yang dilakukan nantinya memberikan kebebasan kepada guru dan siswa melakukan penilaian.

3. Pembuatan RPP pada kebijakan sistem Pendidikan sebelumnya meminta pembuatan RPP secara kaku dan terlalu banyak komponen sehingga menghabiskan waktu guru karena 1 RPP dapat mencapai 10 lembar. Sedangkan dalam kebijakan merdeka belajar, guru diberikan kebebasan memilih, membuat, mengembangkan RPP. Serta guru membuat RPP cukup 1 lembar saja dengan 3 komponen penting ( tujuan, komponen dan asesmen) sedangkan yang lainnya hanyalah pelengkap. Guru membuat RPP secara efektif dan efisien sehingga guru diberikan waktu lebih banyak untuk mempersiapkan pembelajaran dan melakukan asesmen.

4. Membuat PPDB lebih fleksibel, selain itu daerah bebas menetapkan persentase utk PPDB dan Pemerataan akses dan kualitas pendidikan perlu diiringi dengan inisiatif lainnya oleh pemerintah daerah.

Segala kebijakan dalam merdeka belajar diharapkan nantinya dapat dijadikan sebagai solusi dari permasalahan Pendidikan yang dihadapi selama ini.

\section{Surau sebagai sebuah lembaga pendidikan Islam}

Surau diambil dari istilah Melayu-Indonesia yaitu "surau" yang kontraksinya "suro" kata yang luas penggunaannya di Asia Tenggara. Istilah "surau" ini kelihatannya banyak digunakan di Minangkabau, Sumatera Selatan, Semenanjung Malaysia, Sumatera Tengah dan Pattani (Thailand Selatan). Secara bahasa, kata "surau" berarti "tempat" atau "tempat penyembahan". Menurut pengertian asalnya, surau adalah bangunan kecil yang dibangun untuk penyembahan arwah nenek moyang. Awalnya surau dibangun di puncak bukit atau tempat yang lebih tinggi karena alasan sebagai tempat penyembahan nenek moyang. (Maimunah: 2011, 40).

Jika ditelusuri lebih lanjut, surau dibangun dan dikenal jauh sebelum datangnya Islam ke Minangkabau sehingga setelah Islam datang ke Minangkabau terjadi perubahan fungsi dari surau tersebut. Surau yang awalnya sebagai tempat penyembahan arwah nenek moyang menjadi tempat belajar agama Islam. Tidak hanya itu, surau juga dijadikan sebagai tempat rapat, bertemu, belajar adat istiadat, sopan santun, tempat belajar beladiri dan tempat tidur untuk kaum laki-laki serta pusat pembelajaran agama Islam.

Sehingga dapat dikatakan, salah satu komponen dalam kehidupan masyarakat Minangkabau adalah surau. Sedemikian pentingnya surau dalam kehidupan masyarakat Minangkabau, banyak terdapat surau dalam satu nagari. Namun surau tersebut dapat dikategorikan menjadi 3 yaitu surau nagari, surau suku dan surau paham keagamaan. Surau nagari yaitu surau yang didirikan di samping mesjid sebagai persyaratan sebuah nagari, surau suku adalah tempat penghulu/ninik mamak suku dalam pembinaan sopan santun anak kemenakan dan surau paham keagamaan adalah pusat keagamaan dan ibadat suatu paham tarekat seperti surau pasir lubuak nyiur, surau tanjuang limau sundai dengan ulama yang terkenal dengan ajaran tarekatnya(Mas'ud Zein: 2011, 30)

Surau nagari dan surau suku adalah surau yang harus ada dalam setiap suku dan tiap nagari. Sedangkan surau paham keagamaan adalah surau yang dibangun oleh guru/ syekh yang khusus mengajarkan Pendidikan Islam kepada siswa. Selain belajar tarekat didalam surau paham keagamaan, ada beberapa materi Pendidikan Islam yang diberikan oleh guru/ syeikh disesuaikan dengan jenjang Pendidikan yang harus diikuti oleh siswa.

Jenjang Pendidikan tersebut ada 2 macam yaitu (Akhiruddin, 2015: 210-211):

1. Pengajaran al Quran, untuk pengajaran al Quran ada 2 tinkatan yaitu Pendidikan rendah Pendidikan untuk memahami ejaan huruf hijaiyah serta cara mengerjakan ibadah, seperti berwudhu', shalat dan sebagainya. Selain belajar membaca al-Quran dan beribadah, murid surau juga diberikan materi tauhid, seperti sifat dua puluh serta hukum akal yang tiga (wajib, mustahil dan jaiz). Sedangkan materi akhlak diajarkan melalui cerita-cerita seperti kisah Nabi-nabi dan orang-orang shaleh, serta keteladan guru yang diperlihatkan setiap harinya. Setelah menyelesaikan Pendidikan rendah, maka siswa dapat melanjutkan ke Pendidikan tingkat atas. Pendidikan tingkat 
atas memiliki materi Pendidikan Islam membaca Al-Quran dengan lagu, kasidah, berjanji, tajwid, dan kitab perukunan

2. Pengajian kitab. Materi pendidikan pada jenjang ini meliputi; ilmu sharaf dan nahwu, ilmu fiqih, ilmu tafsir, dan ilmu-ilmu lainnya. Cara mengajarkannya adalah dengan membaca sebuah kitab Arab dan kemudian diterjemahkan ke dalam bahasa Melayu. Setelah itu baru diterangkan maksudnya. Penekanan pada jenjang ini adalah pada aspek hafalan. Agar siswa cepat hafal, maka metode pengajarannya dilakukan melalui cara menghafalkan materi dengan lagu-lagu tertentu. Pelaksanaan pada jenjang ini biasanya dilakukan pada siang hari.

Dengan 2 materi Pendidikan dalam surau, guru/ syeikh biasanya mengajarkan siswanya dengan metode halaqah, sebagaimana yang biasa berlaku pada lembaga-lembaga pendidikan Islam tradisional lainnya. Dimana guru/ syeikh dan murid tidak duduk di atas kursi sebagaimana halnya sistem pendidikan modern. Mereka duduk bersila dengan cara membuat lingkaran dan di antara para murid duduk guru tua yang bertugas untuk menuntun dan mengawasi murid secara lebih teliti selama proses belajar mengajar berlangsung. Dalam proses belajar mengajar murid tidak rnempunyai meja atau kursi. Murid hanya memiliki sebuah tempat kitab (tungkuhan) yang cukup untuk meninggikan, agar lebih mudah dalam membaca kitab. Mereka juga memiliki sebuah papan tulis untuk dimanfaatkan tuanku dalarn menjelaskan pelajaran kepada para murid (Mhd. Natsir, 2011:63). Selain metode halaqah, metode lain yang digunakan oleh guru/ syeikh adalah metode ceramaha, membaca dan menghafal. Metode ini disesuaikan dengan materi/ isi pelajaran yang diberikan.

Pendidikan Islam surau juga memiliki sistem evaluasi dan penilaian tersendiri, walaupun sistem evaluasi dan penilaian yang dilakukan di surau belum terstandar. Belum terstandarnya sistem evaluasi dan penilaiankan beberapa faktor yaitu: materi, guru, siswa dan materi ajarnya. Sebagai salah satu contoh, sistem evaluasi dan penilaian pada pengajaran al quran di surau tidak ditentukan oleh waktu/ masa belajar siswanya (Akhiruddin, 2015:211). Seorang siswa baru dikatakan tamat/ menyelesaikan pelajaran al qurannya bila ia telah mampu menguasai materi-materi pengajaran al quran dengan baik. Bahkan adakalanya seorang siswa yang telah menamatkan mempelajari Al-Quran dua atau tiga kali baru berenti dari pengajaran Al-Quran. Begitu juga dengan pengajian kitab, penilaian yang dilakukan sesuai dengan pengajian kitab yang dipakai oleh guru/ syeikh. Pengajian kitab satu surau kadang berbeda dengan surau lainnya, ini juga yang menyebabkan pengajian kitab tidak dapat melakukan penilaian dan asesmen yang sama/ terstandar dari satu surau dengan surau lainnya.

Selain materi tertentu dalam surau, metode, sistem penilaian dan asesmen, murid/ siswa adalah hal yang menarik yang perlu dilihat dalam pembelajaran diadakan surau. Karena murid/ siswa dari surau dapat dijadikan sebagai salah satu indikator keberhasilan surau dan sebagai arah perkembangan Pendidikan Islam (Muhammad furqan, 2019: 9). Murid/ siswa surau biasanya setelah menyelesaikan pendidikan mereka, mereka kembali ke masyarakat dan menyebarkan serta mengembangkan ilmu yang telah didapatkan. Ada beberapa hal yang dapat dijadikan indikator keberhasilan Pendidikan surau dilihat dari segi siswa yaitu: (1) pada masa awal, banyaknya murid-murid yang datang dari berbagai daerah di Minangkabau ke surau Syekh Burhanuddin (surau syekh Burhanuddin merupakan pelopor pendidikan Islam di surau di daerah Minangkabau) untuk mendalami ajaran Islam, (2) semakin banyak muncul surau di daerah Minangkabau yang didirikan oleh "alumni" murid-murid surau Syekh Burhanuddin, (3) lahirnya tokoh ulama besar dan berwibawa dalam mengembangkan dan mengajarkan ajaran Islam di tengah-tengah masyarakat.

Dari 3 indikator tersebut bisa dikatakan bahwa murid/ siswa surau pada umumnya berasal dari daerah Minangkabau tapi tidak menutup kemungkinan murid/ siswa surau juga berasal dari luar Minangkabau. Perlu diingat, pada masa dahulu Minangkabau meliputi 4 provinsi yaitu: sumatera barat, jambi, riau dan Bengkulu (Febri Yulika, 2017: 17). Dengan penjelasan di atas, diketahui murid/ siswa Surau tidak hanya terbatas daerah Sumatera Barat saja tetapi sampai ke daerah Riau, Jambi dan Bengkulu. Karena daerah tersebut merupakan daerah Minangkabau pada masa lampau makanya 3 daerah tersebut juga mengenal istilah surau.

Pendidikan surau yang dianggap sebagai sistem pendidikan tradisional dan khusus belajar agama Islam, ternyata telah memiliki sistem sedemikian rupa yang menjadikan surau sebagai salah satu Lembaga pendidikan Islam terbaik pada masa itu. Surau tidak memiliki sistem pendidikan yang terstandar namun dapat dijadikan sebagai acuan dalam melaksanakan pendidikan Islam saat sekarang. Dengan sistem pendidikan yang diterapkan di surau dianggap hampir sama dengan sistem merdeka belajar saat sekarang ini, jika melihat dari sudut pandang tertentu.

\section{Surau Sebagai Lembaga Pendidikan Alternatif dalam Mewujudkan Merdeka Belajar}

Sesuai dengan Permendiknas No. 22 tahun 2006 mengenai standar isi dari pendidikan tingkat dasar dan menengah, Pendidikan Agama Islam diharapkan mampu menghasilkan manusia yang selalu 
berupaya menyempurnakan iman, takwa, dan berakhlak mulia, akhlak mulia mencakup etika, budi pekerti atau moral sebagai perwujudan dari pendidikan. Tentunya manusia diharapkan dari pendidikan agama Islam adalah seseorang yang tangguh dalam menghadapi tantangan, hambatan dan perubahan yang muncul dalam pergaulan masyarakat baik dalam lingkup lokal, nasional, regional maupun global (Nur Ainiyah:2011, 26)

Dengan tujuan pendidikan Islam di atas sesuai dibutuhkan sebuah sistem Pendidikan yang mampu menciptakan siswa/ murid yang memiliki ketakwaan, budi pekerti, mandiri dan berkarakter. Sistem Pendidikan yang dibutuhkan adalah Pendidikan memiliki kurikulum kompleks yang tidak hanya mementingkan konten/ isi materi ajar saja tetapi juga pengaplikasian dari teori/ konten materi tersebut.

Kurikulum Pendidikan di Indonesia telah banyak mengalami perubahan sejak tahun 1957 dengan istilah rencana pengajaran sampai dengan kurikulum 2013 edisi revisi 2017. Perubahan kurikulum dari tahun 1957 sampai tahun 2017 masih dianggap belum bisa memenuhi tujuan Pendidikan nasional Indonesia.

Tahun 2019 dicanangkan oleh Menteri Pendidikan dan Kebudayaan RI, Nadiem Makarim pendidikan dengan program merdeka belajar. Merdeka belajar tersebut mengharapkan pembelajaran berlangsung lebih nyaman, siswa dapat berdiskusi dengan guru, sehingga dapat membentuk karakter peserta didik yang berani, mandiri, cerdik dalam bergaul, beradab, sopan, berkompetensi, tidak hanya mengandalkan sistem ranking. Nantinya, akan terbentuk para pelajar yang siap kerja dan kompeten, serta berbudi luhur di lingkungan masyarakat.

Merdeka belajar memiliki 4 kebijakan yang membawa perubahan dalam sistem pendidikan nasional Indonesia, yaitu: Ujian Nasional (UN), Ujian Nasional Berstandar Nasional, pembuatan RPP dan PPDB. 4 kebijakan ini dijadikan sebagai solusi dari permasalahan pendidikan dari penetapan kurikulum sebelumnya yang sangat memberatkan bagi pelaksananya. Merdeka belajar juga mendukung pembentukan karakter siswa yang baik, sesuai dengan tujuan pendidikan nasional. Merdeka belajar yang disebut pembelajaran yang menyenangkan, akan memberikan kemungkinan kepada siswa untuk melaksanakan pembelajaran di luar kelas.

Pembelajaran di luar kelas dapat dilakukan siswa dengan masyarakat sehingga mereka bisa mendapatkan makna dari sebuah pembelajaran. Pembelajaran dalam masyarakat dilakukan telah sejak lama, salah satunya dengan pendidikan Islam di surau. Mereka belajar siang ataupun malam berada dalam lingkungan surau dengan pengawasan guru/ syekh dan siswa senior yang telah belajar di surau. Bahkan dari beberapa referensi menyebutkan bahwa ada beberapa surau yang memberikan keterampilan hidup kepada siswanya dengan cara membantu guru/ syekh mereka pada siang hari untuk memenuhi kebutuhan hidup seperti: berternak, berkebun, punya tambak ikan, berdagang dan lain-lain. Pada malam harinya, barulah mereka belajar pada guru/ syekh.

Selain itu, pendidikan Islam di surau tidak mengenal adanya sistem penilaian dan asesmen dengan cara ujian dengan menguji materi dari awal sampai akhir dengan sistem yang kaku, tetapi sistem penilaian dan asesmen dilakukan oleh guru/ syekh sesuai penguasaan materi siswa dengan tidak melihat umur ataupun seberapa lama murid tersebut belajar. Surau tidak mengenal adanya RPP atau rancangan pembelajaran yang ribet. Pembelajaran dilakukan sesuai dengan penguasaan materi murid. Jika dilihat murid tersebut telah menguasai materi dasar/ awal maka akan dilanjutkan pada materi berikutnya yang lebih tinggi. Pembelajaran yang dilakukan tidak tergantung waktu dan rancangan pembelajaran.

Pendidikan Islam di surau tidak mengenal adanya zonasi bagi penerimaan siswa/ muridnya. Ilmu agama yang diberikan oleh guru/ syekh itu tergantung pada guru/ syekh dan muridnya. Bukan kepada tingkat kepintaran ataupun daerah asal dari siswa atau guru. Surau menerima setiap siswa yang akan belajar kepada guru/ syekh.

Kebijakan belajar yang ditetapkan oleh surau dan merdeka belajar sangatlah mirip, sehingga bisa dikatakan bahwa pendidikan Islam di surau sebenarnya telah melaksanakan kebijakan dari merdeka belajar dicanangkan tahun 2019. Tetapi dengan sistem pendidikan lebih fleksibel dan tidak terstruktur.

\section{SIMPULAN}

Dari berbagai uraian di atas dapat diambil kesimpulan: (1) Pendidikan Islam yang ada di surau dapat dijadikan bahan acuan untuk mewujudkan merdeka belajar dengan 4 kebijakan yang disebutkan didalamnya yaitu menekankan pemahaman materi dari pada penguasaan materi ajar. Serta memberikan penilaian lebih bersifat objektif dengan penilaian berdasarkan proses dan hasil. Sistem penilaian dan asesmen dilakukan langsung oleh guru karena guru yang melihat secara langsung pembelajaran dilaksanakan siswa sesuai dengan perkembangannya masing-masing. Serta penerapan sistem zonasi yang lebih fleksibel; (2) Pelaksanaan pendidikan Islam di surau dengan konsep harus belajar dan menginap di surau mungkin tidak dapat dilakukan lagi pada masa sekarang tetapi ada beberapa konsep pendidikan yang bisa diambil dari surau. Termasuk pengajaran al Quran, pengajaran kitab dan keterampilan hidup; (3) Pendidikan yang ada di surau 
merupakan salah satu lembaga pendidikan yang menyeimbangkan antara pendidikan untuk dunia dan akhirat. Maksudnya pendidikan surau memberikan pelajaran agama, norma yang dianut masyarakat, keterampilan serta cara melakukan sosialisasi dengan orang disekitar.

Walaupun surau tidak bisa lagi dijadikan Lembaga pendidikan yang mumpuni bagi siswa masa sekarang tetapi ada beberapa sistem pendidikan Islam yang dilaksanakan oleh surau yang dapat ditiru dan dicontoh. Sistem yang dapat dicontoh tersebut sesuai dengan kurikulum pendidikan nasional dengan sistem merdeka belajar yang dicanangkan pada tahun 2019 .

\section{REFERENSI}

Albertus. Adit. Wikipedia. Gebrakan Merdeka Belajar. Diakses tanggal 06 Oktober 2020

Fathan Robby. (2020). Hardiknas 2020 Merdeka Belajar Di Tengah Covid-19. (http://jurnalposmedia.com/hardiknas-2020-merdeka-belajar-ditengah-covid-19/. Diakses Tanggal 06 Oktober 2020

Febri Yulika. (2017). Epistimologi Minangkabau Makna Pengetahuan dalam Filsafat Adat Minangkabau. Padang Panjang. ISI Padang Panjang

Kementrian Pendidikan dan Kebudayaan RI, pokok-pokok kebijakan Merdeka Belajar. (2019) kementrian pendidikan dan Kebudayaan RI

KM. Akhiruddin. (2015). Lembaga Pendidikan Islam di Nusantara, JURNAL TARBIYA. Volume: 1 No: 1

Maimunah S Moenada. (2011). Surau dan Modernisasi Pendidikan di Masa Hindia Belanda. Jurnal Sosial Budaya. Volume 8 No.1

M. Asri. (2017). Jurnal Modeling. Volume 4, Nomor 2

Mas'oed Abidin. (2016). Surau Kito. Yogyakarta. Gre Publishing

Mas'ud Zein. (2011). Sistem Pendidikan Surau: Karakteristik, Isi dan Literatur Keagamaan. Junal Sosial Budaya. Volume 8 No.1

Mhd. Natsir. (2011). Peranan Surau sebagai Lembaga Pendidikan Islam Tradisional di Padang Pariaman Sumatera Barat (Surau Syaikh Burhanuddin). laporan penelitian, UNP

Muhammad Furqan. (2019). Pesantren sebagai Lembaga Pengembang Masyarakat Islam di Indonesia (Kajian Perspektif Historis). Jurnal Al Ijtimaiyah. Volume 5 No. 1

Nur Ainiyah. (2013). Pembentukan Karakter Melalui Pendidikan Agama Islam. Jurnal Al-Ulum. Volume 13 No. 1

Wiku Aji Sugiri. Sigit Priatmoko. (2020). Perpesktif Asesmen Autentik sebagai Alat Evaluasi dalam Merdeka Belajar. Jurnal at-Thullab, Volume 4 no. 1 